\title{
Randomised multicentre trial of early mobilisation after uncomplicated myocardial infarction
}

\author{
ROBERT R. WEST AND ANDREW H. HENDERSON \\ From the Departments of Community Medicine and Cardiology, Welsh National School of Medicine, \\ Cardiff, Wales
}

SUMMARY In a multicentre trial 742 patients in 13 hospitals in Wales were randomly allocated on the fifth day after uncomplicated myocardial infarction to be mobilised on the fifth or the tenth day. The trial shows no difference in first year mortality, nor in morbidity assessed after a median period of 13 months. Follow-up after one year suggests an unexplained lower mortality during the second and third years in the late mobilisation group.

The trend towards earlier mobilisation after myocardial infarction has been supported now by a number of retrospective studies (Brummer et al., 1966) and controlled trials (Groden et al., 1967; Harpur et al., 1971; Lamers et al., 1973; Royal Infirmary, Glasgow, 1973; Hayes et al., 1974; Abraham et al., 1975). Successive trials have shown a trend towards comparison of earlier mobilisation, starting with the trial of Groden and colleagues in 1967 which showed no adverse effect of mobilising at 15 compared with 25 days. Subsequent trials have likewise shown no disadvantage from mobilising at between 6 and 10 days compared with between 13 and 21 days (Harpur et al., 1971; Lamers et al., 1973; Royal Infirmary, Glasgow, 1973; Abraham et al., 1975), the most meaningful being the relatively large Glasgow study of 538 patients mobilised at 7 compared with 14 days and reported in 1973 (Royal Infirmary, Glasgow, 1973). One more recent trial compared mobilisation at two days with mobilisation at nine days but followup of the 189 patients was very limited (Hayes et al., 1974). In 1972, doctors in Wales were invited to collaborate in a multicentre randomised trial of mobilisation at five days compared with 10 days after uncomplicated myocardial infarction. We here report the results of this trial of 742 patients. The trial differs from previous trials in that it was of relatively early mobilisation and long follow-up, it involved more patients, and it was a multicentre trial with most patients being admitted to district general hospitals.

Received for publication 10 May 1979

\section{Patients and methods}

During 1973 and 1974, 34 doctors in 13 hospitals throughout Wales entered patients into this multicentre trial. Patients eligible for the trial were those aged under 70 years admitted to hospital within 48 hours of the onset of cardiac pain and who fulfilled at least two of three defined criteria for acute myocardial infarction: (i) typical clinical history, (ii) electrocardiographic changes of very probable acute myocardial infarct (World Health Organization 1959), and (iii) serum levels of cardiac enzymes (total creatine kinase or aspartate aminotransferase) more than twice normal for the laboratory in question. On the fifth day (day 5) after clinical onset of the infarct (defined as day 0 ), patients were allocated to be mobilised on day 5 or day 10 according to a randomised sequence of cards provided for each doctor. Patients considered on day 5 to have 'complicated' infarcts were excluded before randomisation at each doctor's discretion: 'complications' listed in the guidelines of the trial procedure included thromboembolic complications or the persistence of heart failure, hypotension, arrhythmias, or cardiac pain. The details of mobilisation day by day were not stipulated and total duration of stay in hospital was not controlled, though guidelines on both these points were given in the procedure. 'Mobilisation' meant sitting out of bed for two halfhour periods on the first day, with subsequently increasing activity until after one week they were out of bed for two hours a day and walking on the level. It was suggested that patients be discharged from hospital about a week after mobilisation. 
Clinical details for each potentially eligible patient were recorded on day 0 and for trial patients also on day 5 and 10. Reasons for exclusion on day 5 were noted.

Follow-up details were obtained at out-patient attendances up to four years after the myocardial infarct in question, as a consequence of inadvertent delays in obtaining data at 12 months as planned. When all attempts at out-patient follow-ups failed (because of non-compliance, migration, or return home after holiday) follow-up information was next sought from the patient's general practitioner. This left $62(8 \%)$ of the 746 original trial entrants for whom final tracings had to be sought from the National Health Service central register. Registrations with family practitioner committees provided evidence that 50 of these 62 patients remained alive, eight had died, and four remained untraced. These four patients have been excluded from the trial and from all calculations. The trial is therefore concerned with a total of 742 trial entrants. Mortality for the two groups was calculated using life table survivorship to three years and was compared by Mantel Haenzel test. Other comparisons were by $x^{2}$ for non-parametric statistics (numbers with arrhythmia, dyspnoea, etc.) and by t test for parametric distributions (heart rate, blood pressure).

\section{Results}

Table 1 shows age and sex distribution of the 1035 patients, of whom $293(28 \%)$ were excluded from entry into the trial on day 5 because of complications and $742(72 \%)$ were entered into the trial on day 5 . The characteristics of the early and the late mobilisation groups and of the group excluded from the trial are compared in Tables 1 to 4 . Table 3 shows the interval between onset of cardiac pain and admission: in all groups about half the patients were admitted within four hours of the onset of cardiac pain and nearly a third within two hours. Patients excluded from the trial included a higher proportion with a

Table 1 Age and sex of patients

\begin{tabular}{|c|c|c|c|c|c|c|}
\hline \multirow[t]{2}{*}{ Age } & \multicolumn{2}{|c|}{ Mobilised on day 5} & \multicolumn{2}{|c|}{ Mobilised on day 10} & \multicolumn{2}{|c|}{$\begin{array}{l}\text { Unfit on day } 5 \\
\text { (excluded from }\end{array}$} \\
\hline & $\boldsymbol{M}$ & $F$ & $M$ & $F$ & $M$ & $\boldsymbol{F}$ \\
\hline $\begin{array}{r}-34 \\
35-44 \\
45-54 \\
55-64 \\
65-69\end{array}$ & $\begin{array}{r}4 \\
30 \\
107 \\
123 \\
36\end{array}$ & $\begin{array}{r}0 \\
4 \\
9 \\
25 \\
9\end{array}$ & $\begin{array}{r}4 \\
34 \\
109 \\
130 \\
54\end{array}$ & $\begin{array}{r}0 \\
2 \\
12 \\
26 \\
24\end{array}$ & $\begin{array}{r}0 \\
16 \\
69 \\
125 \\
38\end{array}$ & $\begin{array}{r}0 \\
2 \\
10 \\
19 \\
14\end{array}$ \\
\hline Total & 300 & 47 & 331 & 64 & 248 & 45 \\
\hline
\end{tabular}

No significant differences.
Table 2 Past history: numbers of patients (percentages in brackets)

\begin{tabular}{llcl}
\hline & $\begin{array}{l}\text { Mobilised on } \\
\text { day 5 } \\
n=347\end{array}$ & $\begin{array}{l}\text { Mobilised on } \\
\text { day 10 } \\
n=395\end{array}$ & $\begin{array}{l}\text { Unfit on } \\
\text { day 5 } \\
n=293\end{array}$ \\
\hline $\begin{array}{l}\text { Myocardial infarct } \\
\text { Angina }\end{array}$ & $10(3)$ & $8(2)$ & $15(5)$ \\
Hypertension & $89(26)$ & $126(32)$ & $94(32)$ \\
Diabetes & $28(8)$ & $54(14)^{\star}$ & $51(17)^{\star \star}$ \\
& $5(1)$ & $13(3)$ & $10(3)$ \\
\hline
\end{tabular}

*Significant difference at $\mathbf{P}<0.05$ (comparing day 5 mobilisation with day 10 mobilisation).

$\star \star$ Significant difference at $P<0.01$ (comparing unfit on day 5 with trial entrants).

past history of hypertension (Table 2) and with arrhythmias, severe cardiac pain, severe dyspnoea, bradycardia ( $<60 / \mathrm{min}$ ), tachycardia $(>120 / \mathrm{min}$ ), or hypotension (systolic pressure $<120 \mathrm{mmHg}$ ) on admission; a higher proportion showed electrocardiographic evidence of 'very probable infarct' and raised cardiac enzymes (Table 4).

Of the 742 patients entered into the trial, 347 $(47 \%)$ patients were mobilised on day 5 and 395 $(53 \%)$ on day 10 . The two groups were shown to be well matched for sex and age (Table 1), past history of myocardial infarct, angina and diabetes (Table 2), and arrhythmia, severity of cardiac pain and dyspnoea, and recorded blood pressure, both on admission (Table 4) and on day 5. The only differences identified were a higher proportion of patients with known hypertension in the late mobilisation group (Table 2), and a higher mean heart rate on admission in the early mobilisation group (Table 4). There were no significant differences between the groups in numbers of patients being given oxygen, anticoagulants, antiarrhythmics, diuretics, or analgesics, either on admission or on day 5 .

Survival curves for the first year for the 742 patients, calculated from the moment of randomisation on day 5, are shown in the Figure. There are no

Table 3 Interval between onset of cardiac pain and admission to hospital (percentages in brackets)

\begin{tabular}{llll}
\hline Interval $(\boldsymbol{h})$ & $\begin{array}{l}\text { Mobilised on } \\
\text { day 5 }\end{array}$ & $\begin{array}{l}\text { Mobilised on } \\
\text { day } 10\end{array}$ & Unfit on day 5 \\
\hline-2 & $101(29)$ & $119(30)$ & $87(30)$ \\
$3-4$ & $71(20)$ & $85(22)$ & $58(20)$ \\
$5-8$ & $65(19)$ & $76(19)$ & $46(16)$ \\
$9-12$ & $39(11)$ & $44(11)$ & $38(13)$ \\
$13-24$ & $39(11)$ & $32(8)$ & $23(8)$ \\
$25-48$ & $22(6)$ & $22(6)$ & $24(8)$ \\
\hline Not recorded & $10(3)$ & $17(4)$ & $17(6)$ \\
\hline Total & 347 & 395 & 293 \\
\hline
\end{tabular}

No significant differences. 
Table 4 Clinical findings on admission

\begin{tabular}{|c|c|c|c|}
\hline & $\begin{array}{l}\text { Mobilised } \\
\text { on day } 5 \\
n=347\end{array}$ & $\begin{array}{l}\text { Mobilised } \\
\text { on day } 10 \\
n=395\end{array}$ & $\begin{array}{l}\text { Unfit on } \\
\text { day } 5 \\
n=293\end{array}$ \\
\hline \multirow{6}{*}{$\begin{array}{l}\text { Electrocardiogram shows } \\
\text { very probable infarct } \\
\text { Enzymes (over twice } \\
\text { normal) } \\
\text { Arrhythmia } \\
\text { Severe cardiac pain } \\
\text { Severe dyspnoea }\end{array}$} & \multicolumn{3}{|c|}{ Numbers (percentages in brackets) } \\
\hline & $208(61)$ & $244(62)$ & $216(74)^{\star \star \star}$ \\
\hline & $266(79)$ & $304(81)$ & $252(91)^{\star \star \star}$ \\
\hline & $55(16)$ & $82(21)$ & $100(35)^{\star \star \star}$ \\
\hline & $47(14)$ & 70 (18) & $65(22)^{\star}$ \\
\hline & $15(4)$ & $13(3)$ & $26(9) \star \star$ \\
\hline & \multicolumn{3}{|c|}{ Mean \pm standard deviation } \\
\hline Heart rate & $87 \pm 20 \dagger \dagger$ & $83 \pm 18$ & $86 \pm 25$ \\
\hline Systolic blood pressure & $149 \pm 29$ & $149 \pm 28$ & $144 \pm 31^{\star}$ \\
\hline
\end{tabular}

$\star$ Significant differences at $P<0.05, \star \star P<0.01$, and $\star \star \star$ at $P<0.001$ comparing unfit on day 5 with trial entrants.

t†tSignificant difference at $P<0.001$ comparing day 5

mobilisation with day 10 mobilisation.

significant differences in survival at one year between those mobilised on day 5 (41 deaths) and those mobilised on day 10 (42 deaths), and no significant difference for any month during the first year. The data in respect of mortality are complete for these 742 trial entrants (the four patients remaining untraced having been excluded from further consideration, see Methods). Data for survival beyond one year is also available but for diminishing numbers $(51 \%$ of the 742 trial entrants at 13 months, $24 \%$ at 24 months, and $9 \%$ at 36 months). These data suggest a possible trend towards better survival during the second and third

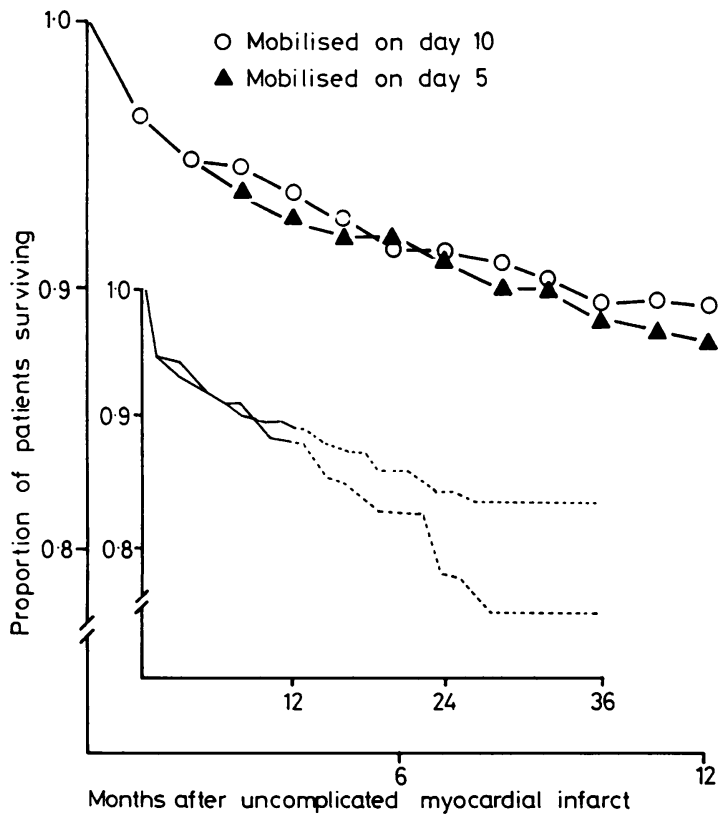

Fig. Patient survival after uncomplicated myocardial infarct.
Table 5 Time of follow-up assessment : months after entry to trial

\begin{tabular}{|c|c|c|}
\hline Months & $\begin{array}{l}\text { Mobilised on day } 5 \\
\text { Number (percentage) }\end{array}$ & $\begin{array}{l}\text { Mobilised on day } 10 \\
\text { Number (percentage) }\end{array}$ \\
\hline 8 & $3(1)$ & $4(1)$ \\
\hline 9 & 9 (3) & $6(2)$ \\
\hline 10 & $9(3)$ & 8 (3) \\
\hline 11 & $26(10)$ & $31(10)$ \\
\hline 12 & 85 (32) & $93(30)$ \\
\hline 13 & $32(12)$ & $21(7)$ \\
\hline 14 & $14(5)$ & $28(9)$ \\
\hline 15 & $13(5)$ & 7 (2) \\
\hline 16 & $5(2)$ & 7 (2) \\
\hline 17 & 3 (1) & $7(2)$ \\
\hline 18 & 3 (1) & $12(4)$ \\
\hline$\overline{19-24}$ & $\overline{11}(4)$ & $22(7)$ \\
\hline $25-30$ & 15 (6) & $25(8)$ \\
\hline $31-36$ & $21(8)$ & $20(6)$ \\
\hline $37+$ & $16(6)$ & $25(8)$ \\
\hline Total & 265 & 316 \\
\hline
\end{tabular}

years in the day 10 mobilisation group (eight deaths) than in the day 5 group ( 15 deaths, $P<0.05$ ) (see inset to Figure).

Morbidity was also assessed. Full clinical followups were completed for 581 patients $(90 \%$ of surviving trial entrants). It had been the intention that follow-up should be at 12 months after entry into the trial. Approximately half the patients were seen during 11 th, 12th, or 13th months but inadvertently many were not followed up until later, the median follow-up assessment being 13 months in both groups (Table 5). At follow-up assessment there was no difference between the trial groups in the number of non-fatal reinfarctions that had occurred (20 in the day 5 mobilisation group and 19 in the day 10 group), nor in the features listed in Table 6.

Mortality was similarly analysed for subgroups of trial entrants identified by possible 'risk features'

Table 6 Follow-up assessment

\begin{tabular}{llc}
\hline & $\begin{array}{l}\text { Mobilised on } \\
\text { day } 5 \\
n=265\end{array}$ & $\begin{array}{l}\text { Mobilised on } \\
\text { day } 10 \\
n=316\end{array}$ \\
& $\begin{array}{l}\text { Number (percentage in brackets) } \\
10(4)\end{array}$ & $16(5)$ \\
Confined to bed & $29(11)$ & $43(14)$ \\
Not physically active & $15(6)$ & $15(5)$ \\
$\begin{array}{l}\text { Angina at rest or limiting normal } \\
\text { activity }\end{array}$ & $92(35)$ & $103(33)$ \\
$\begin{array}{l}\text { Angina on mild or severe exertion } \\
\text { Dyspnoea at rest or limiting }\end{array}$ & $13(5)$ & $15(5)$ \\
normal activity & $104(40)$ & $123(39)$ \\
Dyspnoea on mild or severe & $9(3)$ & $18(6)$ \\
$\quad$ exertion & Mean & standard deviation \\
Arrhythmia & $80 \pm 12$ & $79 \pm 11$ \\
Heart rate & $145 \pm 22$ & $144 \pm 25$ \\
Systolic blood pressure & &
\end{tabular}

No significant differences. 
Table 7 Survival of patients with potential 'risk features': life table survival at 12 months (numbers died in brackets)

\begin{tabular}{llll}
\hline $\begin{array}{l}\text { Potential 'risk feature' } \\
\text { on admission }\end{array}$ & $\begin{array}{l}\text { Mobilised on } \\
\text { day } 5\end{array}$ & $\begin{array}{l}\text { Mobilised on } \\
\text { day 10 }\end{array}$ & $\begin{array}{l}\text { Mobilised on } \\
\text { day } 5 \text { or on } \\
\text { day 10 }\end{array}$ \\
\hline History of hypertension & $0.63(10)^{\star \star \star}$ & $0.83(9)$ & $0.76(19) \star \star \star$ \\
Arrhythmia & $0.78(12)^{\star}$ & $0.92(6)$ & $0.87(18)$ \\
Severe cardiac pain & $0.89(5)$ & $0.81(12)^{\star}$ & $0.85(17)$ \\
Severe dyspnoea & $0.73(4)^{\star \star}$ & $0.69(4)^{\star \star}$ & $0.71(8)^{\star \star}$ \\
Bradycardia (HR $<60)$ & $0.81(3)$ & $0.97(1)$ & $0.92(4)$ \\
Tachycardia (HR > 120) & $0.67(8)^{\star \star \star}$ & $0.64(5)^{\star \star}$ & $0.66(13)^{\star \star \star}$ \\
$\begin{array}{l}\text { Systolic BP }<120 \\
\text { Systolic BP > 180 }\end{array}$ & $0.86(6)$ & $0.83(10)$ & $0.85(16)$ \\
\hline All patients admitted & $0.88(6)$ & $0.83(10)$ & $0.85(16)$ \\
\hline & $0.88(41)$ & $0.89(42)$ & $0.89(83)$ \\
\hline
\end{tabular}

$\star$ Significant differences at $\mathrm{P}<0.05$, $\star \star_{\text {at }} \mathrm{P}<0.01$, and $\star \star \star P<0.001$ comparing survival of patients with 'risk features' with survival of all patients admitted to the trial.

(Table 7). Patients with a previous history of hypertension, or with tachycardia or severe dyspnoea on admission experienced significantly poorer survival at one year. Arrhythmia or severe cardiac pain on admission showed possibly poorer survival.

Average stay in hospital was 13 days for the early mobilisation group and 16 days for the late mobilisation group. Early mobilisation in practice thus led to earlier discharge and resulted in lower costs to the National Health Service.

\section{Discussion}

The early mobilisation and the late mobilisation groups were comparable with respect to age, sex, previous history, interval between onset of cardiac pain and admission to hospital, clinical findings on admission, and treatment. Known hypertension was commoner in the late mobilisation group, but mean heart rate on admission was higher in the early mobilisation group, these two 'risk features' possibly balancing each other out with respect to first year mortality (Table 7). No obvious evidence of 'rule-breaking' was found to account for the slight excess of patients in the day 10 group. The trial shows no significant difference in the first year mortality, nor in morbidity assessed after a median period of 13 months. The largest similar trial previously carried out compared mobilisation after seven days and 14 days and also showed no disadvantage of early mobilisation (Royal Infirmary, Glasgow, 1973). More recently Abraham and colleagues showed fewer late non-fatal complications among 64 patients mobilised on day 6 compared with 65 on day 13, followed up for less than a year (Abraham et al., 1975). In the only previous trial comparing earlier mobilisation a total of 189 patients were followed up for only six weeks (Hayes et al.,
1974). The present relatively large multicentre trial adds considerable support to the idea that mobilisation as early as day 5 is not detrimental.

Follow-up of trial patients after one year, albeit with reducing numbers, showed an unexpected trend towards lower mortality in the late mobilisation group. There appears to have been no obvious bias towards day 5 or day 10 mobilisation groups among those patients included in this late followup, nor any recognised difference between the representatives of day 5 and day 10 mobilisation groups with respect to the 'risk features' as listed in Table 7. Though the early mobilisation group as a whole had a higher mean heart rate on admission, a mismatch in respect of this 'risk feature' does not readily explain the widening difference in survival curves seen only after the first year of follow-up, and it was further shown that the deaths after the first year were not in fact associated with any of the identified 'risk features'. The trend towards a lower late mortality in the day 10 group remains unexplained.

This trial was carried out in district general hospitals throughout the region, in contrast to previous more centralised mobilisation trials. The conclusion that there is no significant difference in first year mortality or in morbidity after a median period of 13 months appears therefore to be of general application to all hospitals and has financial implications about costs borne by the National Health Service for patients admitted to hospital with uncomplicated acute myocardial infarction.

We are grateful to Professor A. L. Cochrane, Professor J. R. Muir, and the Working Party in Cardiology of the Welsh Hospital Board for initiating the study. We are greatly indebted to the many doctors, nurses, secretaries, and records staff who collaborated (a list of participating physicians is given below.) $)^{1}$ Most of all we thank Mrs Elaine

${ }^{1}$ The following consultants collaborated in this Welsh multicentre trial:

Professor A. W. Asscher, Cardiff; Dr P. Beck, Cardiff; Dr A. G. Chappell, Bridgend; Dr G. A. Coles, Cardiff; Dr E. A. Danino, Swansea; Dr L. A. G. Davidson, Cardiff; Dr F. L. Dyson, Neath; Dr R. B. Evans, Cardiff; Dr O. P. Galpin, Llandudno; Dr R. Greenwood, Cardiff; Dr J. N. Harris Jones, Swansea; Dr I. M. Hayes, Cardiff; Dr. A. H. Henderson, Cardiff; Dr N. Hodges, Bangor; Dr S. T. H. Jenkins, Aberystwyth; Dr J. H. Jones, Cardiff; Dr G. S. Kilpatrick, Cardiff; Dr D. G. Lewin, Caerphilly; Dr G. H. T. Lloyd, Rhyl; Dr O. Lloyd, Neath; Professor R. H. Mahler, Cardiff; Dr O. K. Makinson, Bangor; Dr. R. T. Maxwell, Bangor; Dr D. E. Meredith, Rhyl; Dr J. M. Morris, Bridgend; Professor J. R. Muir, Cardiff; Dr N. Oliver, Pontypridd; Dr. W. Phillips, Cardiff; Dr. J. Rhodes, Cardiff; Dr P. M. Smith, Cardiff; Dr J. de Sweit,

Pontypridd; Dr A. J. Thomas, Cardiff; Dr J. P. Thomas, Cardiff; Dr F. K. Wright, Rhyl. 
Elkington who co-ordinated all data collection throughout the trial and follow-up.

\section{References}

Abraham, A. S., Sever, Y., Weinstein, M., Dollberg, M., and Menczel, J. (1975). Value of early mobilisation in patients with and without complications after acute myocardial infarction. New England fournal of Medicine, 292, 719-722.

Brummer, P., Kallio, V., and Tala, E. (1966). Early ambulation in the treatment of myocardial infarction. Acta Medica Scandinavica, 180, 231-234.

Groden, B. M., Allison, A., and Shaw, G. B. (1967). Management of myocardial infarction. Scottish Medical fournal, $12,435-440$.

Harpur, J. E., Conner, W. T., Hamilton, M., Kellett, R. J., Galbraith, H. J. B., Murray, J. J., and Swallow, J. H. (1971). Controlled trial of early mobilisation and discharge from hospital in uncomplicated myocardial infarction. Lancet, 2, 1331-1334.
Hayes, M. J., Morris, G. K., and Hampton, J. R. (1974). Comparison of mobilization after two and nine days in uncomplicated myocardial infarction. British Medical fournal, 3, 10-13.

Lamers, H. J., Drost, W. S. J., Kroon, B. J. M., van Es, L. A., Meilink-Hoedemaker, L. J., and Birkenhäger, W. H. (1973). Early mobilization after myocardial infarction: a controlled study. British Medical fournal, 1, 257-259.

Royal Infirmary, Glasgow, Medical Division (1973). Early mobilisation after uncomplicated myocardial infarction. Lancet, 2, 346-349.

World Health Organization (1959). Hypertension and coronary heart disease: classification and criteria for epidemiological studies. World Health Organization. Technical Report Series, 168. The Organization, Geneva.

Requests for reprints to $\operatorname{Dr}$ A. H. Henderson, Department of Cardiology, Welsh National School of Medicine, Heath Park, Cardiff CF4 4XN. 